\title{
Seedborne Fungal Contamination: Consequences in Space-Grown Wheat
}

\author{
Deborah L. Bishop, Howard G. Levine, Bradley R. Kropp, and Anne J. Anderson
}

First, third, and fourth authors: Department of Biology, Utah State University, Logan 84322-5305; second author: Dynamac Corporation, DYN 3, Kennedy Space Center, Cape Canaveral, FL 32899.

Accepted for publication 5 July 1997.

\begin{abstract}
Bishop, D. L., Levine, H. G., Kropp, B. R., and Anderson, A. J. 1997. Seedborne fungal contamination: Consequences in space-grown wheat. Phytopathology 87:1125-1133.

Plants grown in microgravity are subject to many environmental stresses that may promote microbial growth and result in disease symptoms. Wheat (cv. Super Dwarf) recovered from an 8-day mission aboard a NASA (National Aeronautics and Space Administration) space shuttle showed disease symptoms, including girdling of leaf sheaths and chlorosis and necrosis of leaf and root tissues. A Neotyphodium species was isolated from the seed and leaf sheaths of symptomatic wheat used in the spaceflight mission. Certain isozymes of a peroxidase unique to extracts from the microgravity-grown plants were observed in extracts from earthgrown Neotyphodium-infected plants but were not present in noninfected wheat. The endophytic fungus was eliminated from the wheat seed by
\end{abstract}

ABSTRACT

Plant-microbe interactions rarely have been considered significant components of the plant growth experiments thus far conducted in space. Although it has been possible to maintain asepsis for short-term plant growth studies in microgravity $(19,20)$, this approach is unrealistic for longer flights, when environmental recycling and food production will be required (5). The spaceflight environment is not sterile, and microbes that can colonize plants have been isolated from spaceflight hardware $(4,26,30,31)$. The few investigations available report a general pattern of increased growth rates for microbial organisms exposed to microgravity (10, 14,33).

Plant growth in space may provide a greater opportunity for potential pathogens to colonize plants and, thus, facilitate pathogenesis. Under the controlled environments in spaceflight experiments, plants are subjected to environmental stresses, including elevated carbon dioxide $\left(\mathrm{CO}_{2}\right)$, low photosynthetic photon flux density, and high relative humidity $(\mathrm{RH})$. Plant growth and metabolism are altered in microgravity, e.g., key enzymes associated with lignification change, less vigorous and abnormal seed is produced, and photosynthetic rate and light-saturated electron transport is decreased $(7,12,32)$. These conditions and changes in plant physiology may affect host defenses and make plants more susceptible to infection by pathogens and organisms that normally do not cause disease. The work in this paper originated as a result of the CHROMEX-06 spaceflight experiment conducted aboard the U.S. space shuttle Discovery during the STS-63 mission. The original goal was to investigate the effect of microgravity on the activity and composition of peroxidases in wheat (Triticum aesti-

Corresponding author: A. J. Anderson

E-mail address: Anderson@biology.usu.edu

Publication no. P-1997-0828-01R

(C) 1997 The American Phytopathological Society prolonged heat treatment at $50^{\circ} \mathrm{C}$ followed by washes with water at $50^{\circ} \mathrm{C}$. Plants from wheat seed infected with the Neotyphodium endophyte were symptomless when grown under greenhouse conditions, whereas symptoms appeared after only 4 days of growth in closed containers. Disease spread from an infected plant to noninfected plants in closed containers. Dispersion via spores was found on asymptomatic plants at distances of 7 to $18 \mathrm{~cm}$ from infected plants. The size and shape of the conidia, mycelia, and phialide-bearing structures and the ability to grow rapidly on carbohydrates, especially xylose, resembled the characteristics of $N$. chilense, which is pathogenic on orchard grass, Dactylis glomerata. The Neotyphodium wheat isolate caused disease symptoms on other cereals (wheat cv. Malcolm, orchard grass, barley, and maize) grown in closed containers.

Additional keywords: fungal endophyte.

vum L. 'Super Dwarf'). Although the seeds underwent a rigorous seed surface-sterilization, nearly one-half of the seedlings returned from the mission with visual fungal contamination. We report on studies conducted to understand the source of contamination and the damage to wheat caused by the fungi. Our findings are the first to document colonization of wheat by a Neotyphodium species.

\section{MATERIALS AND METHODS}

Plant growth in spaceflight environments. Seventy-two wheat (cv. Super Dwarf) plants were grown in a plant growth unit (PGU) in a middeck locker of the U.S. space shuttle Discovery during an 8-day mission. The PGU housed six individual, enclosed plant growth chambers (PGCs). Prior to planting, seed was surface-sterilized by submersion in $70 \%$ ethanol for $1 \mathrm{~min}$ and $25 \%$ sodium hypochlorite containing $0.2 \%$ Triton $\mathrm{X}-100$ with vigorous shaking at $200 \mathrm{rpm}$ for $20 \mathrm{~min}$. Seed was rinsed five times with sterile deionized water $\left(22^{\circ} \mathrm{C}\right)$ and transferred to sterile petri dishes containing $22 \mathrm{ml}$ of $2.0 \%$ water agar supplemented with $0.5 \%$ sucrose. Plated seeds were kept at $4^{\circ} \mathrm{C}$ for 4 days to synchronize germination. Twelve 36 -h-old germinated seedlings were planted ( $24 \mathrm{~h}$ prior to lift-off) in individual Nitex $(50-\mu$ mesh nylon; Teckco Inc., Lancaster, NY) planting pockets fitted into the foam base in each PGC. Foam root barriers were placed in each planting pocket on both sides of each seedling.

Environmental parameters used for plant growth are described by Krikorian and Levine (16) and Levine and Krikorian (18). Each foam base was supplied with $200 \mathrm{ml}$ of sterile one-half strength Schenk and Hildebrandt (SH) nutrient medium (27) supplemented with $0.5 \%$ sucrose prior to planting. Plants were grown under a 24-h photoperiod, with light intensities ranging from 30 to $60 \mu \mathrm{mol} \mathrm{m} \mathrm{m}^{-2} \mathrm{~s}^{-1}, 90$ to $100 \% \mathrm{RH}$, and carbon dioxide that increased from ambient to $150,000 \mathrm{ppm}$ by the end of the mission. Ground-control plants were grown under the same environmental conditions as the flight 
plants (except for microgravity and other spaceflight-associated factors, such as increased levels of radiation plus launch and landing vibration loads) supplied by an orbital environmental simulation chamber at the John F. Kennedy Space Center, Cape Canaveral, FL. Sections of leaf sheath and meristematic tip regions were cultured on potato dextrose agar (PDA; Difco Laboratories, Detroit) from the space-flown plants at the end of the mission to culture microbial contaminants.

Wheat seed sources. Spring wheat (T. aestivum) cv. Super Dwarf initially was obtained from CIMMYT, Mexico City, by B. Bugbee, Plant Soils and Biometerology Department, Utah State University, Logan, who grew additional accessions (lots 1, 2, and 4). Seed lot 1 was grown in 1991 under greenhouse conditions. Seed lot 2, used in both U.S. space shuttle (STS-63) and U.S. NASA (National Aeronautics and Space Administration)/Russian Mir wheat experiments in 1995, was derived by multiplication of the 1991 seed under greenhouse conditions in 1993. Seed lot 3 was obtained from seed lot 2 by growth in a mixture of 1:1 peat/vermiculite under greenhouse conditions, with high light intensity $\left(1,000 \mu \mathrm{mol} \mathrm{m} \mathrm{m}^{-2} \mathrm{~s}^{-1}\right)$, day and night temperatures of 22 and $17^{\circ} \mathrm{C}$ respectively, $50 \% \mathrm{RH}$, and adequate nutrients. Seed lot 4 was distributed to the NASA Centers for use in plant space biological research. Endophyte-free seed lot 5 was obtained by a $50^{\circ} \mathrm{C}$ heat treatment, as described below, and increased in sterile environmental-control chambers. A newly released wheat seed cultivar, USU-Apogee (lot 6), which was bred specifically for space-related research (B. Bugbee, Utah State University), also was examined for endophytic contamination.

Identification of endophytes. Seed was surface-sterilized, as described above, with ethanol and sodium hypochlorite treat-
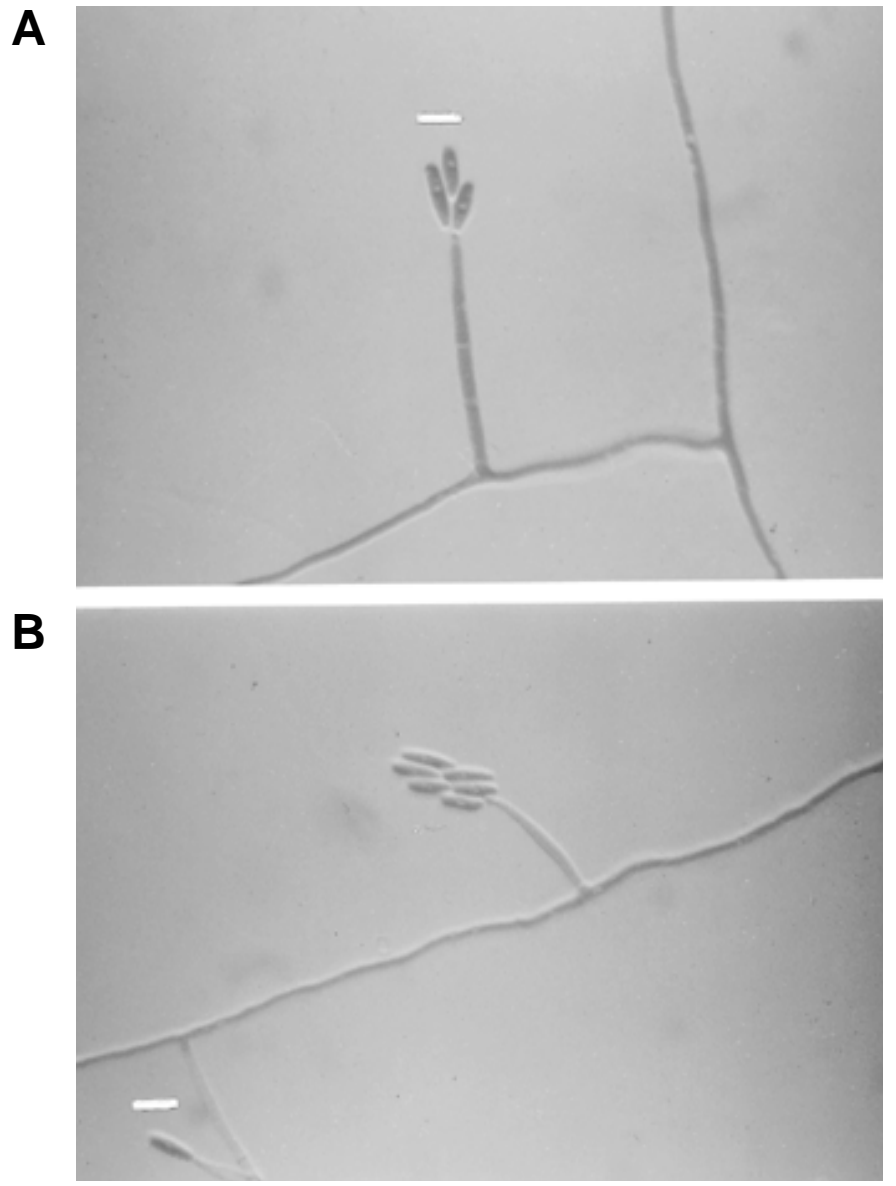

Fig. 1. Morphology of fungal mycelia, phialide structures, and conidiospores from the Neotyphodium isolate from A, wheat cv. Super Dwarf, compared to those from $\mathbf{B}$, the fescue isolate, $N$. coenophialum. The preparations were from 14-day-old potato dextrose agar plates and were stained with an aniline blue, lactic acid stain, as described in text. The bar represents $10 \mu \mathrm{m}$. ments. Fungi isolated from the seed after growth on PDA plates for 2 weeks were purified by dilution plating to obtain single spores. Conidia were suspended in $5 \mathrm{ml}$ of sterile double-deionized water and filtered through siliconized glass wool to remove any mycelia prior to storage or use. Fungi were cultured also from sections of diseased wheat leaves that returned from the space mission. The fungal isolates were stored at $-80^{\circ} \mathrm{C}$ in $15 \%$ glycerol, either as a plug of mycelium from a PDA plate or as a pure spore suspension. Cultures were maintained by transfer of inoculum plugs, $\approx 1 \mathrm{~cm}$ in diameter, to fresh PDA plates every 14 days.

Morphological characteristics of spores, mycelia, and plategrown colonies $(23,24,34,36)$ were used in the identification of the Neotyphodium isolate recovered from microgravity-exposed wheat leaves. The isolate was compared to $N$. coenophialum isolated from seed of endophytic Festuca arundinacea (cv. Kentucky 31), as described above. A $1 \%$ aqueous, aniline blue, lactic acid stain (2) was used to stain hyphae and spores. Photographs were obtained under $100 \times$ magnification. Colony diameters (millimeters) and the coloration of the mycelium on the reverse side of growth plates were examined on $1.8 \%$ water agar and Murashige and Skoog medium (25) amended with $4 \%$ filter-sterilized fructose, glucose, mannose, sucrose, or xylose to further characterize the Neotyphodium species (24).

Immunoblot analysis with polyclonal antibodies raised against $N$. coenophialum (provided by C. West, University of Arkansas, Fayetteville, in collaboration with T. Jones, USDA Forage and Range Facility, Logan, UT) was performed with proteins extracted from the Neotyphodium isolates from fescue and wheat grown for 2 weeks on PDA plates or from germinated seeds of endophytepositive wheat and fescue. Proteins extracted from 2-week-old mycelia of Fusarium culmorum (strain 409), a wheat pathogen $(17,28)$, and from germinated aseptic Super Dwarf seeds served as controls. Proteins were extracted by grinding $0.2 \mathrm{~g}$ of mycelial mass in liquid nitrogen prior to transfer to $0.2 \mathrm{ml}$ of $50 \mathrm{mM}$ phosphate buffer, $\mathrm{pH}$ 6.0. The extracts were boiled for $2 \mathrm{~min}$ in sodium dodecyl sulfate (SDS) buffer (13), and $20 \mu \mathrm{g}$ of protein of each sample was separated on a $10 \%$ polyacrylamide gel by SDS-polyacrylamide gel electrophoresis (SDS-PAGE). Proteins were transferred to an Immobilon membrane (Boehringer Mannheim, Indianapolis, IN) with a Bio-Rad (Hercules, CA) electrophoretic transfer

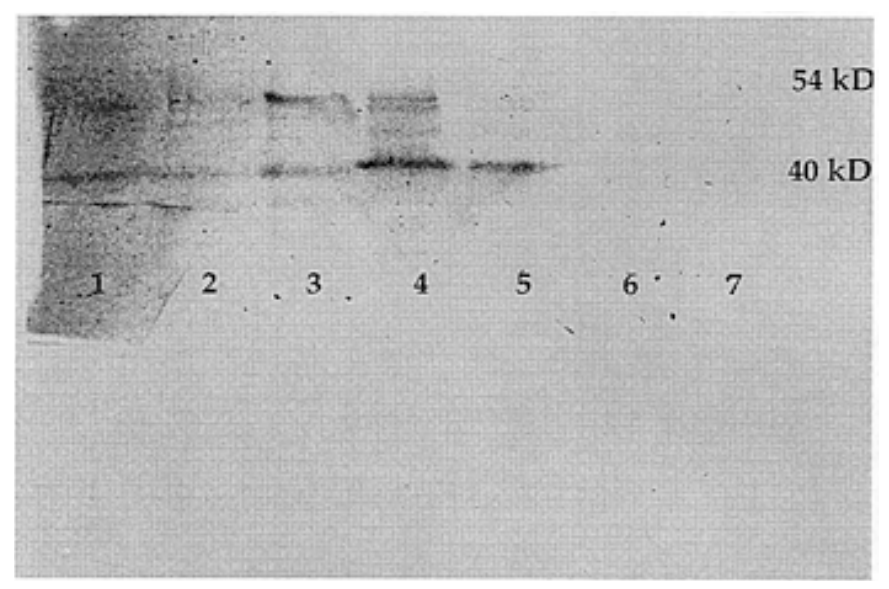

Fig. 2. Immunodetection of protein from wheat and fescue Neotyphodium isolates, with antibody generated to $N$. coenophialum. Neotyphodium-specific polyclonal antibodies were reacted with extracts from lane 1, Neotyphodium mycelia isolated directly from surface-sterilized endophytic Festuca arundinacea, or lane 2, wheat cv. Super Dwarf seeds (lot 2) after germination on potato dextrose agar (PDA); lane 3, mycelia of $N$. coenophialum after growth on PDA for 2 weeks; lane 4, mycelia of the Neotyphodium isolate from wheat after growth on PDA for 2 weeks; lane 5, mycelia of the Neotyphodium isolate from Achaetherum robustrum after growth on PDA for 2 weeks; lane 6, negative control, heat-treated, endophyte-free 14-day-old cv. Super Dwarf germinated on PDA; and lane 7, Fusarium culmorum mycelia after growth on PDA for 2 weeks. Procedures were as described in text. 
apparatus set at $8 \mathrm{~mA}$ for $1 \mathrm{~h}$. An identical gel with an additional protein standard to determine molecular weight was stained for total protein with Coomassie blue (13). The nitrocellulose membrane was allowed to react with the antibodies to Neotyphodium before treatment with a protein A-alkaline phosphatase conjugate (Sigma Chemical Co., St. Louis) and detection of alkaline phosphatase activity (11).

Generation of endophyte-free seed. Seed was submersed in sterile double-deionized water containing $0.2 \%$ Triton X-100 and incubated with vigorous shaking at $150 \mathrm{rpm}$ for $40 \mathrm{~min}$ at temperatures of either 22,40 , or $50^{\circ} \mathrm{C}$. This procedure was done twice. After incubation, the seed was washed three times with sterile double-distilled water equilibrated to the incubation temperature. The seed was surface-sterilized by immersion in $25 \%$ sodium hypochlorite containing $0.2 \%$ Triton X-100, washed five times with sterile water, transferred to plates of PDA, and incubated at $22^{\circ} \mathrm{C}$. The type of endophytic contamination, percent seed sterility, and germination were recorded for each of the treatments.

Seed surface-sterilization treatments. Seeds were immersed in concentrated $(96.4 \%)$ sulfuric acid $\left(\mathrm{H}_{2} \mathrm{SO}_{4}\right)$ for $5 \mathrm{~min}$ or $30 \%$ hydrogen peroxide $\left(\mathrm{H}_{2} \mathrm{O}_{2}\right)$ for $10 \mathrm{~min}$, followed by extensive washing in sterile distilled water. Seeds were transferred to plates of PDA, kept at $4{ }^{\circ} \mathrm{C}$ for 4 days to synchronize germination, and kept at $22^{\circ} \mathrm{C}$ under incandescent lighting to assess percent sterility and germination over an 8-day period.

Establishment of symptoms on wheat and other hosts. Symptoms caused by inoculation of wheat cv. Super Dwarf with the Neotyphodium isolate from wheat were compared to symptoms on microgravity-grown wheat. Endophyte-free seed (lot 5) was surfacesterilized with $25 \%$ sodium hypochlorite in $0.2 \%$ Triton X-100 with shaking for $20 \mathrm{~min}$ at $200 \mathrm{rpm}$. After five rinses with sterile distilled water, seed was immersed in a suspension of Neotyphodium spores $\left(10^{6}\right.$ spores per $\left.\mathrm{ml}\right)$ in $1 \%$ carboxy-methylcellulose for $2 \mathrm{~min}$, which was obtained as described above from a 2-weekold Neotyphodium culture on PDA. Five seeds were transferred to each Magenta box (Magenta Corporation, Chicago) containing sterilized vermiculite $(200 \mathrm{ml})$ and sterile water $(100 \mathrm{ml})$. Each treatment consisted of 100 seeds, and each treatment was replicated five times. The closed boxes were placed at $26^{\circ} \mathrm{C}$ under a $24-\mathrm{h}$ photoperiod provided by incandescent lighting $\left(110 \mu \mathrm{mol} \mathrm{m} \mathrm{m}^{-2} \mathrm{~s}^{-1}\right)$ for 8 days. As a control, seed was treated with sterile water instead of the spore suspension.

This procedure was repeated with other cereals-fescue, orchard grass, wheat cv. Malcom, barley cv. Steptoe, and maize cv. Spancross - to examine the potential of the Neotyphodium isolate from wheat to cause disease on other plant species. Symptoms on each inoculated host plant were recorded at 8 and 16 days for five separate

TABLE 1. Colony diameters of Neotyphodium isolates from Festuca arundinacea and Triticum aestivum on agar amended with $4 \%$ fructose, glucose, mannose, sucrose, or xylose

\begin{tabular}{lcc}
\hline & \multicolumn{2}{c}{ Colony diameter $(\mathrm{mm})^{\mathrm{z}}$} \\
\cline { 2 - 3 } Carbohydrate & Neotyphodium wheat isolate & N. coenophialum \\
\hline Fructose & $60 \pm 5 \mathrm{a}$ & $6.4 \pm 2 \mathrm{~b}$ \\
Glucose & $48 \pm 3 \mathrm{~b}$ & $0.8 \pm 2 \mathrm{c}$ \\
Mannose & $45 \pm 5 \mathrm{~b}$ & $11 \pm 4 \mathrm{a}$ \\
Sucrose & $32 \pm 2 \mathrm{c}$ & $9.3 \pm 3 \mathrm{a}$ \\
Xylose & $46 \pm 5 \mathrm{~b}$ & $0.3 \pm 2 \mathrm{c}$ \\
\hline
\end{tabular}

${ }^{y}$ Media were inoculated with a plug $(1 \mathrm{~cm}$ diameter) from 8-day-old potato dextrose agar cultures of Neotyphodium isolates.

${ }^{z}$ Plates were incubated at $26^{\circ} \mathrm{C}$, and colony diameters were measured at day 30. Data were transformed by a log transformation and subjected to twoway factorial analysis. Data are represented as means with the standard error of five replicated samples for each of two trials. Colony diameter on various carbohydrate-containing media was significantly greater for the Neotyphodium wheat isolate compared to the Neotyphodium fescue isolate $(\alpha=$ 0.05 ). Means in the same column followed by the same letter are not significantly different. trials. A dose-response relationship was examined by inoculating the seed with suspensions of $10^{2}, 10^{3}, 10^{4}, 10^{5}, 10^{6}$, and $10^{7}$ spores per $\mathrm{ml}$. Emergence was recorded at 8 days and symptoms at 16 days. The presence of Neotyphodium was confirmed by transferring sections of the diseased wheat stems to plates of PDA and observing the characteristic coloration of the mycelium and the size and shape of the spores and phialides. These studies were performed twice, with two replicates each.

The potential for fungal dispersion from Neotyphodium-infected Super Dwarf seed was evaluated by planting a single, surfacesterilized Neotyphodium-infested seed from lot 2 in a Nitex planting pocket in each of six PGCs. The other 11 pockets were planted with surface-sterilized, heat-treated, endophyte-free seeds. The plants were grown under conditions similar to those used in spaceflight: high RH (greater than $90 \%$ ), a stable temperature of $28^{\circ} \mathrm{C}$, and low incandescent lighting during a 24 -h photoperiod. Plants were watered and fertilized with one-half strength SH nutrient medium (27). Observations of microbial spread and symptom development on neighboring plants were recorded daily, and plants were inspected microscopically at 8 days for five separate trials.

Endophyte-infected wheat seed (lot 2) was planted under open greenhouse conditions to produce asymptomatic plants or in closed containers to permit symptom development. Sections of leaves, sheaths, and roots stained with $1 \%$ aqueous aniline blue, lactic acid stain (2) were examined microscopically at $100 \times$ magnification

TABLE 2. Effect of heat treatment and washing on elimination of microbes from wheat seed

\begin{tabular}{|c|c|c|c|c|}
\hline $\begin{array}{l}\text { Seed lot } \\
\text { (year) }\end{array}$ & $\begin{array}{c}\text { Temperature } \\
\text { treatment } \\
\left({ }^{\circ} \mathrm{C}\right)^{\mathrm{y}}\end{array}$ & $\begin{array}{c}\text { Water wash } \\
\left({ }^{\circ} \mathrm{C}\right)^{\mathrm{y}}\end{array}$ & $\begin{array}{c}\text { Seeds without } \\
\text { contamination } \\
(\%)^{\mathrm{z}}\end{array}$ & $\begin{array}{c}\text { Germination } \\
(\%)^{\mathrm{z}}\end{array}$ \\
\hline 1 (1991) & $\begin{array}{l}22 \\
40 \\
50 \\
50\end{array}$ & $\begin{array}{l}22 \\
40 \\
40 \\
50\end{array}$ & $\begin{aligned} 7 & \pm 4.0 \mathrm{~d} \\
17 & \pm 6.0 \mathrm{c} \\
67 & \pm 16.0 \mathrm{~b} \\
100 & \pm 0.0 \mathrm{a}\end{aligned}$ & $\begin{array}{l}52 \pm 10.7 \mathrm{c} \\
66 \pm 5.3 \mathrm{~b} \\
74 \pm 11.3 \mathrm{a}, \mathrm{b} \\
80 \pm 5.0 \mathrm{a}\end{array}$ \\
\hline 2 (1993) & $\begin{array}{l}22 \\
40 \\
50 \\
50\end{array}$ & $\begin{array}{l}22 \\
40 \\
40 \\
50\end{array}$ & $\begin{array}{c}7 \pm 3.3 \mathrm{~d} \\
20 \pm 3.3 \mathrm{c} \\
70 \pm 13.3 \mathrm{~b} \\
100 \pm 0.0 \mathrm{a}\end{array}$ & $\begin{array}{l}55 \pm 10.0 \mathrm{~b} \\
73 \pm 4.0 \mathrm{a} \\
74 \pm 2.6 \mathrm{a} \\
95 \pm 6.7 \mathrm{a}\end{array}$ \\
\hline 3 (1993) & $\begin{array}{l}22 \\
40 \\
50 \\
50\end{array}$ & $\begin{array}{l}22 \\
40 \\
40 \\
50\end{array}$ & $\begin{array}{r}28 \pm 6.0 \mathrm{~d} \\
42 \pm 7.3 \mathrm{c} \\
74 \pm 9.3 \mathrm{~b} \\
100 \pm 0.0 \mathrm{a}\end{array}$ & $\begin{array}{l}78 \pm 6.3 \mathrm{~b} \\
77 \pm 4.0 \mathrm{~b} \\
81 \pm 5.3 \mathrm{~b} \\
89 \pm 5.3 \mathrm{a}\end{array}$ \\
\hline 4 (1995) & $\begin{array}{l}22 \\
40 \\
50 \\
50\end{array}$ & $\begin{array}{l}22 \\
40 \\
40 \\
50\end{array}$ & $\begin{array}{l}70 \pm 13.3 \mathrm{c} \\
80 \pm 6.0 \mathrm{~b}, \mathrm{c} \\
89 \pm 5.3 \mathrm{~b} \\
99 \pm 2.7 \mathrm{a}\end{array}$ & $\begin{array}{l}87 \pm 4.0 \mathrm{a}, \mathrm{b} \\
80 \pm 13.3 \mathrm{~b} \\
84 \pm 5.3 \mathrm{~b} \\
94 \pm 5.3 \mathrm{a}\end{array}$ \\
\hline 5 (1995) & $\begin{array}{l}22 \\
40 \\
50 \\
50\end{array}$ & $\begin{array}{l}22 \\
40 \\
40 \\
50\end{array}$ & $\begin{array}{r}98 \pm 4.0 \mathrm{a} \\
99 \pm 6.0 \mathrm{a} \\
100 \pm 0.0 \mathrm{a} \\
100 \pm 0.0 \mathrm{a}\end{array}$ & $\begin{array}{l}86 \pm 5.3 \mathrm{a} \\
85 \pm 3.3 \mathrm{a} \\
88 \pm 4.0 \mathrm{a} \\
87 \pm 14.6 \mathrm{a}\end{array}$ \\
\hline 6 (1996) & $\begin{array}{l}22 \\
40 \\
50 \\
50\end{array}$ & $\begin{array}{l}22 \\
40 \\
40 \\
50\end{array}$ & $\begin{array}{r}83 \pm 5.0 \mathrm{c} \\
86 \pm 6.0 \mathrm{c} \\
92 \pm 0.0 \mathrm{~b} \\
100 \pm 0.0 \mathrm{a}\end{array}$ & $\begin{array}{l}80 \pm 5.1 \mathrm{~b} \\
87 \pm 3.0 \mathrm{a} \\
89 \pm 2.0 \mathrm{a} \\
90 \pm 3.6 \mathrm{a}\end{array}$ \\
\hline
\end{tabular}

y Seed was subjected twice to heat treatments at temperatures of 22,40 , or $50^{\circ} \mathrm{C}$ for $40 \mathrm{~min}$ each and to water washes equilibrated to the indicated temperatures. After the heat treatment protocol, seed was surface-sterilized with $70 \%$ ethanol for $1 \mathrm{~min}$ and $25 \%$ sodium hypochlorite for $20 \mathrm{~min}$ before washing five times with sterile double-deionized water.

${ }^{z}$ Seed was examined for the presence of endophytic contaminants, as described in text, and germination was assessed. Data were transformed with an arcsine square-root transformation and are represented as back-transformed means with a standard error of five replications, each with 100 seeds. Significant differences in percent seeds without contamination and germination between heat treatments were apparent in seed lots 1 through 4 and 6 $(\alpha=0.05)$. Endophyte-free seed lot 5 showed no difference in percent seed without contamination and germination for these treatments. Means in the same column and seed lot followed by the same letter are not significantly different. 
for the presence of fungal hyphae and spores. This experiment was repeated three times.

Statistical analyses. Data for percent sterility and germination were subjected to arcsine square-root transformation. Log transformation of colony diameters was analyzed by analysis of variance. Comparisons of means were made by Tukey's multiple comparison test at $\alpha=0.05$.

Peroxidase composition. Peroxidase isozymic composition from microgravity- and earth-grown plants was compared to that from Neotyphodium-infected and noninfected plants. Leaf sheaths and roots were ground in $0.01 \mathrm{M} \mathrm{K}_{2} \mathrm{HPO}_{4}, 0.2 \mathrm{M} \mathrm{KCl}, \mathrm{pH} 6.0$, buffer at $4^{\circ} \mathrm{C}$, and cell debris was removed by high-speed centrifugation, $15,000 \times g$ (SS34 rotor; Sorvall Instruments, Du Pont Co., Wilmington, DE) for $5 \mathrm{~min}$ at $4^{\circ} \mathrm{C}$. Peroxidase isozyme composition in $1 \mu \mathrm{g}$ of protein, as determined by a bicinchoninic acid assay (Pierce Chemical Co., Rockford, IL), was examined by isoelectric focusing (22). Ampholytes (Pharmacia Biotech, Uppsala, Sweden) were used at $1.0 \%$ in the $\mathrm{pI}$ range of 3 to 10 . Gels were run at $4^{\circ} \mathrm{C}$ and $4 \mathrm{~W}$ of constant power for $1 \mathrm{~h}$, increasing to $8 \mathrm{~W}$ for $2 \mathrm{~h}$. Gels were stained for peroxidase activity in Tris buffer $(\mathrm{pH} 7.5)$, with $0.15 \%$ (wt/vol) hydrogen peroxide and catechol $/ p$-phenyldiamine as the substrates $(1,22)$. The isoelectric points of the proteins were determined by isoelectric point markers (FMC BioProducts, Rockland, ME).

\section{RESULTS}

Growth under spaceflight conditions. Approximately $50 \%$ of the initial 72 seedlings (lot 2) grown for 8 days in microgravity aboard the U.S. space shuttle Discovery showed signs of fungal contamination, including abundant white cottony aerial mycelium with profuse mycelial growth on elevated roots, leaf sheaths, and wheat culms. The leaves of infected plants were chlorotic, twisted, and necrotic at the tips. Similar symptoms were observed in about $30 \%$ of the control plants grown under identical conditions on the ground.

Identification of Neotyphodium from seed. Endophytic fungi were isolated from cv. Super Dwarf seed (lot 2) used in the spaceflight mission. Mycelia emerged from seed as it germinated on PDA plates. Two fungi were observed most frequently from lot 2 seed. One was identified as a Cladosporium species (34) by its spore characteristics and brown to black mycelium. This fungus is a known seedborne endophyte of wheat (28). The second fungus was identified as a Neotyphodium species, based on the size and morphology of conidia and conidiogenous cells and colony characteristics in vitro $(8,23,24,34,36)$. The small hyaline conidia produced white to slightly pink or tan mycelia, with tan to brown coloration on the reverse side of the PDA plates after 2 weeks. The smooth, hyaline conidia were slightly oblong with an obtuse apex and were $\approx 10$ to $20 \mu \mathrm{m}$ long and 1 to $2 \mu \mathrm{m}$ wide. The size and morphology of conidia and fungal mycelia from pure cultures of the Neotyphodium isolate from wheat are shown in Figure 1 compared to $N$. coenophialum, an endophyte of fescue. The conidia and spore-bearing phialides are characteristic of other Neotyphodium species $(8,15,23,24,34,36)$, with a close resemblance to those of $N$. chilense (24) previously isolated from Dactylis glomerata.

Antibodies raised against $N$. coenophialum (Fig. 2) reacted with two proteins of 54 and $40 \mathrm{kDa}$ in mycelial extracts prepared from isolates of Neotyphodium from wheat, fescue, and sleepy grass grown on PDA. Proteins extracted from Fusarium culmorum and noninoculated wheat cv. Super Dwarf did not react with the Neotyphodium-specific antibodies. Our results confirm the finding that the polyclonal antibodies raised against Neotyphodium recognize different Neotyphodium species.

The Neotyphodium isolate from wheat cv. Super Dwarf grew more rapidly on PDA and produced more conidia than $N$. coenophialum isolated from fescue (Table 1). Its ability to grow rapidly and form sectors on xylose- and glucose-containing media clearly distinguished the wheat isolate from $N$. coenophialum. These characteristics and the potential of the Neotyphodium isolate from wheat to cause disease are similar to traits of $N$. chilense from $D$. glomerata (24).

The fungus cultured from the leaf sheaths of space-flown plants had the same growth characteristics as the Neotyphodium isolate from wheat seed (lot 2). Neotyphodium also was isolated from

TABLE 3. Effect of surface-sterilization procedures on elimination of microbial endophytes from wheat cv. Super Dwarf seed

\begin{tabular}{|c|c|c|c|c|}
\hline \multirow[b]{3}{*}{ Treatment $^{\mathrm{y}}$} & \multicolumn{4}{|c|}{ Seed lot $(\text { year })^{\mathrm{z}}$} \\
\hline & \multicolumn{2}{|c|}{$4(1995)$} & \multicolumn{2}{|c|}{$5(1995)$} \\
\hline & Without contamination $(\%)$ & Germination $(\%)$ & Without contamination (\%) & Germination (\%) \\
\hline Concentrated $\mathrm{H}_{2} \mathrm{SO}_{4}$ & $0 \pm 0.0 \mathrm{c}$ & $80 \pm 10.3 \mathrm{a}$ & $99 \pm 2.7 \mathrm{a}, \mathrm{b}$ & $87 \pm 5.3 b$ \\
\hline $30 \% \mathrm{H}_{2} \mathrm{O}_{2}$ & $10 \pm 20.0 \mathrm{c}$ & $82 \pm 6.3 \mathrm{a}$ & $100 \pm 0.0 \mathrm{a}$ & $95 \pm 2.6 \mathrm{a}$ \\
\hline Sodium hypochlorite & $70 \pm 13.3 b$ & $87 \pm 4.0 \mathrm{a}$ & $98 \pm 4.0 \mathrm{~b}$ & $86 \pm 5.3 b$ \\
\hline Sodium hypochlorite and $50^{\circ} \mathrm{C}$ & & & & \\
\hline
\end{tabular}

y Surface-sterilization and $50^{\circ} \mathrm{C}$ heat treatments were performed, and the extent of microbial contamination and germination of wheat seed were assessed on potato dextrose agar, as described in text.

${ }^{\mathrm{z}}$ Data were transformed by arcsine square-root transformation and are represented as back-transformed means with standard error of five replications, each with 100 seeds. There was a significant seed lot-treatment interaction for percent sterility with the alternative sterilization protocols for seed lots 4 and $5(\alpha=0.05)$. Seed lots 4 and 5 also showed overall differences in percent symptoms and germination among the sterilization treatments $(P \leq 0.001)$. Means in the same column followed by the same letter are not significantly different.

TABLE 4. Response of wheat cultivars to inoculation by Neotyphodium spores

\begin{tabular}{|c|c|c|c|c|c|c|c|c|}
\hline \multirow[b]{2}{*}{ Cultivar $^{\mathrm{Z}}$} & \multirow[b]{2}{*}{ Plant response } & \multicolumn{6}{|c|}{ Inoculum dose (spores per ml) } & \multirow[b]{2}{*}{0} \\
\hline & & $10^{2}$ & $10^{3}$ & $10^{4}$ & $10^{5}$ & $10^{6}$ & $10^{7}$ & \\
\hline Malcom & $\begin{array}{l}\text { Emerged } \\
\text { Diseased }\end{array}$ & $\begin{array}{r}7 \pm 2 \\
10 \pm 3\end{array}$ & $\begin{array}{r}4 \pm 2 \\
12 \pm 3\end{array}$ & $\begin{array}{r}3 \pm 1 \\
13 \pm 2\end{array}$ & $\begin{array}{r}1 \pm 0 \\
14 \pm 0\end{array}$ & $\begin{array}{r}3 \pm 2 \\
14 \pm 1\end{array}$ & $\begin{array}{r}3 \pm 2 \\
15 \pm 0\end{array}$ & $\begin{array}{r}15 \\
0\end{array}$ \\
\hline Super Dwarf & $\begin{array}{l}\text { Emerged } \\
\text { Diseased }\end{array}$ & $\begin{array}{r}11 \pm 1 \\
5 \pm 2\end{array}$ & $\begin{array}{l}9 \pm 2 \\
5 \pm 2\end{array}$ & $\begin{array}{r}12 \pm 1 \\
8 \pm 1\end{array}$ & $\begin{array}{r}12 \pm 3 \\
9 \pm 2\end{array}$ & $\begin{array}{r}9 \pm 2 \\
10 \pm 3\end{array}$ & $\begin{array}{l}10 \pm 1 \\
12 \pm 3\end{array}$ & $\begin{array}{r}15 \\
0\end{array}$ \\
\hline
\end{tabular}

${ }^{\mathrm{z}} \mathrm{Cv}$. Malcom or Super Dwarf seed was inoculated with spores of Neotyphodium at concentrations of $10^{2}$ to $10^{7}$ spores per ml, as described in text. The plants were grown for 8 days, and emergence was scored. Disease was scored at 16 days. Data are the number of plants that emerged or were diseased from a total of 15 planted seeds. The study was repeated twice, and the mean with the standard error is provided. 
seed lots 1, 3, and 4 of Super Dwarf when seed was subjected only to surface-sterilization protocols. In collaboration with W. Campbell at Utah State University, Logan, we demonstrated that the Neotyphodium endophyte also was present in seed lot 2 used in the NASA/Mir mission. Wheat cv. USU-Apogee also contained seedborne endophytes but to a lesser extent. Approximately $4 \%$ of Apogee seed was infected with the Neotyphodium endophyte. This degree of infection is less than the level observed with cv. Super Dwarf, the maternal parent of USU-Apogee.

Elimination of seedborne endophytes. Heat treatment of seed at $50^{\circ} \mathrm{C}$ in addition to surface-sterilization treatments consistently eliminated endophytes (Table 2). Heat treatments at $40^{\circ} \mathrm{C}$ followed by subsequent water washes equilibrated at $40^{\circ} \mathrm{C}$ reduced the amount of contamination by $10 \%$ compared to seed that received only a surface-sterilization treatment. Heat treatment at $50^{\circ} \mathrm{C}$ with a $40^{\circ} \mathrm{C}$ water wash further decreased fungal growth from the seed by $\approx 35 \%$. Prolonged heat treatment at $50^{\circ} \mathrm{C}$ followed by $50^{\circ} \mathrm{C}$ equilibrated washes completely eliminated endophytic fungi from seed without reducing germination. There were significant differences in percent symptoms between heat treatments in seed lots 1 through 4 and $6(P \leq 0.001)$ (Table 2$)$.

To test the efficacy of our methods to generate endophyte-free seed, seed from lots 2 and 3 was subjected to the $50^{\circ} \mathrm{C}$ heat treatment and $50^{\circ} \mathrm{C}$ wash protocol. Seedlings were grown for 8 days in PGCs identical to those used in the CHROMEX-06 spaceflight experiment for three separate trials. There were no disease symptoms and no visible fungal growth on roots or leaves. Sections of root and leaf tissues from these plants were free of any microbial contamination when examined microscopically. The seed generated from lot 5 seed was endophyte-free (Tables 2 and 3) and produced disease-free seedlings.

Alternative surface-sterilization treatments involving immersion in concentrated sulfuric acid and $30 \%$ hydrogen peroxide for $10 \mathrm{~min}$ did not eliminate seedborne endophytes (Table 3 ). There was a significant seed lot-treatment interaction for percent sterility with the alternative sterilization protocols for seed lots 4 and $5(P \leq 0.001)$. Seed lots 4 and 5 also showed overall differences in percent sterility and germination compared to the sterilization treatments (Table 3) $(P \leq 0.001)$.

Neotyphodium and symptoms on infected wheat. After surface-sterilization and growth in closed containers, seedlings from lots 2 and 4 displayed symptoms identical to those observed on the spaceflight mission. Similar symptoms also were observed in plants grown from lot 5 after inoculation with Neotyphodium spores and growth in closed containers. There was abundant mycelial growth and profuse sporulation on the outer surfaces of both leaf and root tissues beginning 8 days after inoculation. The conidia and spore-bearing phialides on symptomatic plants resembled the structures observed from pure cultures of Neotyphodium grown on PDA plates. Symptomatic wheat had a cottony ring of mycelia
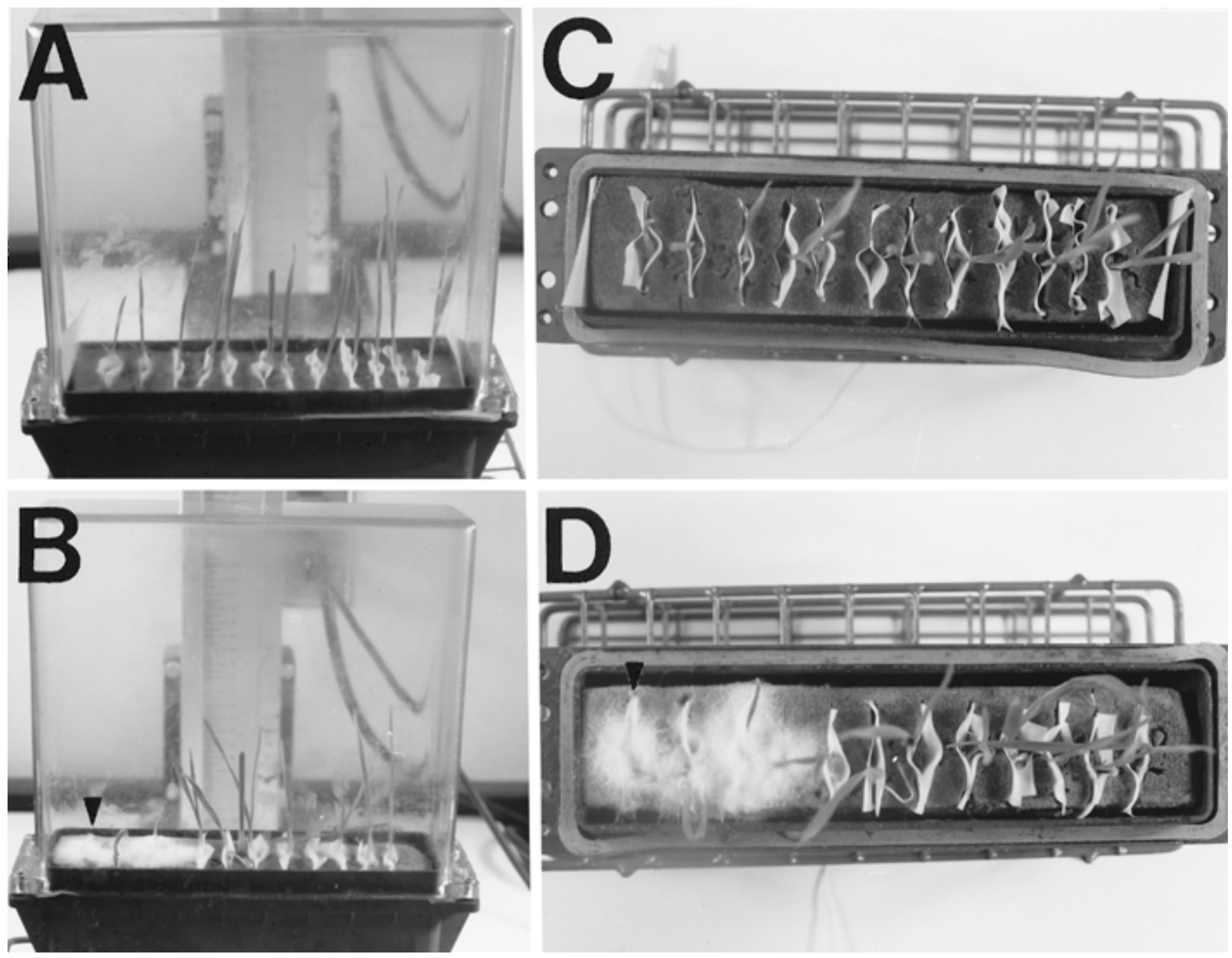

Fig. 3. Growth of wheat cv. Super Dwarf for 8 days in prototype plant growth chambers used in U.S. space shuttle missions. Chambers A and C were planted with endophyte-free, heat-treated seed from lot 2. Chambers B and D were planted with 1 Neotyphodium-infected seed from lot 2 (arrow) and 11 other endophyte-free seeds. 
girdling the leaf sheaths, whereas leaves appeared chlorotic and twisted at growing points. Root surfaces were brown and had profuse mycelial growth. Control plants raised from noninoculated seed from lot 5 lacked these symptoms or any detectable fungal growth when grown in closed Magenta boxes or open in the greenhouse.

The extent of symptoms on wheat was related to the inoculation dose of Neotyphodium spores provided to the seed (Table 4). Cv. Super Dwarf showed symptoms even when inoculated with $10^{2}$ spores per ml. Emergence of cv. Super Dwarf was less affected by Neotyphodium than was cv. Malcom (Table 4). Cvs. Apogee and Tam 107 were even more sensitive, with disease evident on all plants at an inoculum dose of $10^{2}$ spores per ml (S. I. Kwon and A. J. Anderson, unpublished data). Inoculation of cv. Super Dwarf seed with $10^{6}$ spores per $\mathrm{ml}$ resulted in clear symptom development within 8 days and, therefore, was employed in our subsequent experiments. Disease from symptomatic plants grown from naturally endophyte-infected (lot 2) seed spread to seedlings grown from endophyte-free (lot 5) seed in the enclosed PGCs housed in a proto-

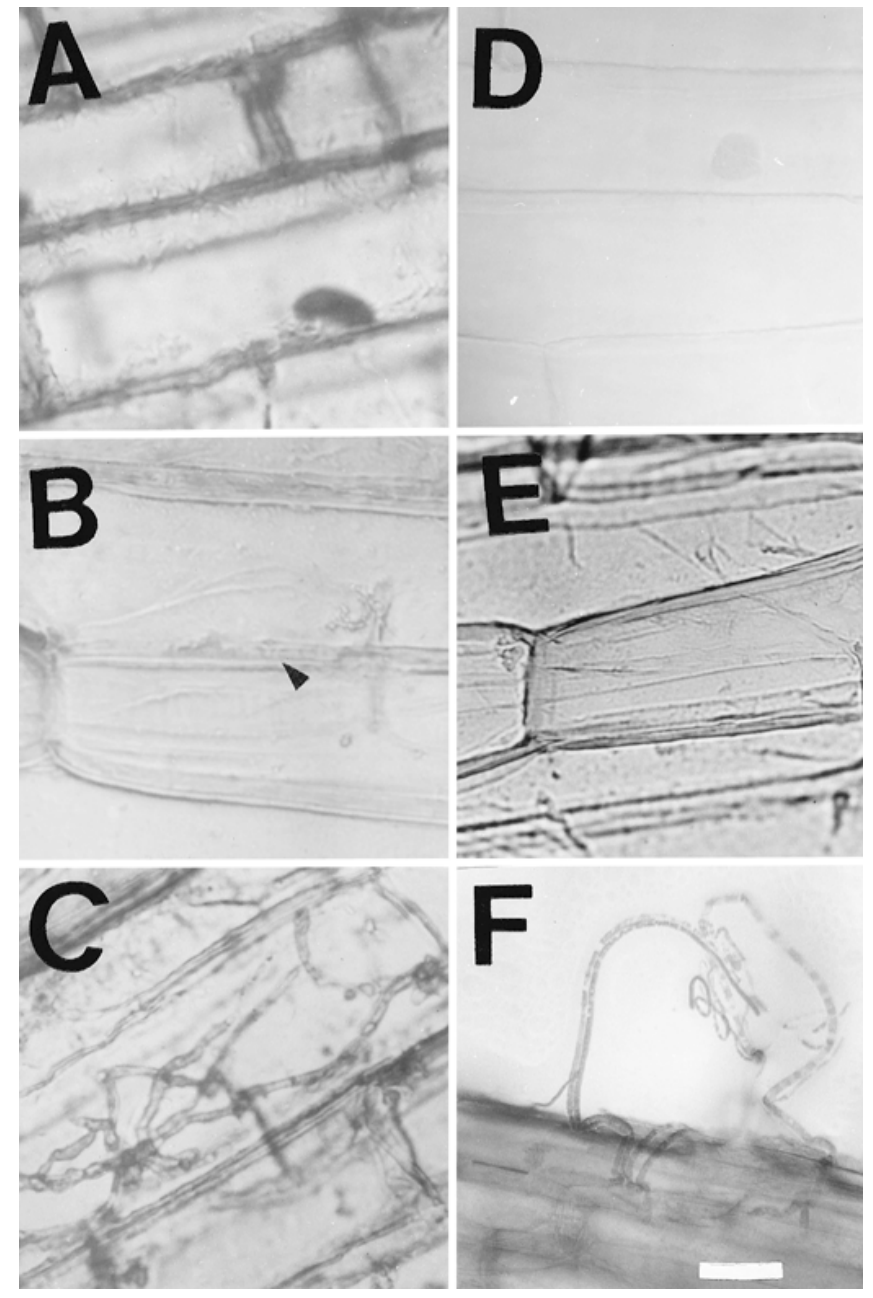

Fig. 4. Histochemical staining of endophyte-free and symptomatic 8-day-old wheat cv. Super Dwarf. Endophyte-free plants were raised in closed Magenta (Magenta Corporation, Chicago) boxes from seed (lot 5). Asymptomatic plants were generated from endophyte-infected seed (lot 2) grown under open greenhouse conditions. Symptomatic plants were from seed (lot 5) inoculated with a spore suspension of the Neotyphodium isolate from wheat and grown in closed Magenta boxes. Tissues were stained with aniline blue, lactic acid and photographed under 100x magnification with brightfield microscopy, as described in text. A, Endophyte-free leaf sheath; B, Neotyphodium-infected asymptomatic leaf sheath, the arrow shows the position of hyphae growing intercellularly through the plant cell wall; $\mathbf{C}$, Neotyphodium-infected symptomatic leaf sheath; $\mathbf{D}$, endophyte-free root; $\mathbf{E}$, asymptomatic root; and $\mathbf{F}$, root from Neotyphodium-infected symptomatic plant. The bar represents $10 \mu \mathrm{m}$. type PGU. The plants receiving secondary inoculum showed mild to severe disease symptoms after 4 to 5 days (Fig. 3). By 8 days, conidia were found by microscopic inspection on the outer surfaces of leaf sheaths and leaves of asymptomatic plants at a distance of 7 to $18 \mathrm{~cm}$ from the Neotyphodium-infected seed source in the enclosed PGCs.

Microscopic examination of wheat leaf sheaths and root tissues of cv. Super Dwarf was used to further delineate the growth of the Neotyphodium fungus in asymptomatic and symptomatic seedlings. Only intercellular hyphae were present in the leaf sheaths of asymptomatic plants, which were obtained from naturally endo-

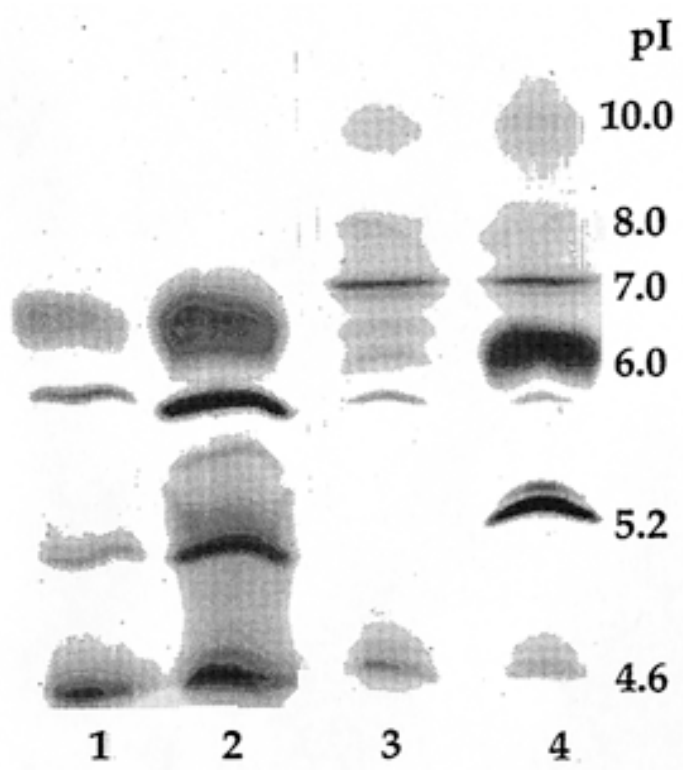

Fig. 5. Isozymic composition of total peroxidases from wheat roots (lanes 1 and 2) and leaves (lanes 3 and 4) after growth for 8 days in microgravity (lanes 2 and 4) or on earth in an orbital simulation chamber (lanes 1 and 3). Plants were grown from endophyte-infected wheat cv. Super Dwarf seed (lot 2). Total proteins were separated by isoelectric focusing gel electrophoresis and stained for peroxidase activity. The isoelectric points of the marker proteins are shown on the right.

\section{$\underset{10.0}{\mathrm{pI}}$ \\ 8.0}

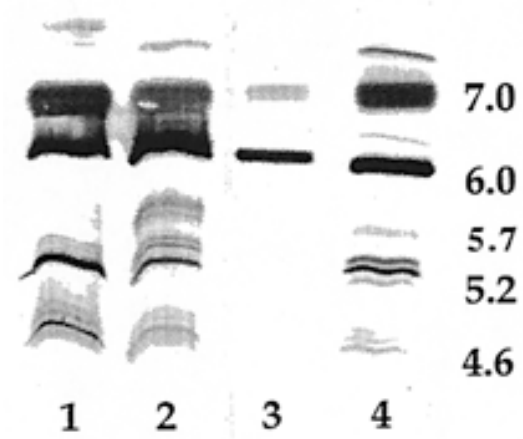

Fig. 6. Isozymic composition of total peroxidases from roots (lanes 1 and 2) and leaf sheaths (lanes 3 and 4) from 8-day-old wheat plants grown from Neotyphodium-inoculated (lanes 2 and 4) and noninoculated (lanes 1 and 3) seed from lot 5 . Total proteins were separated by isoelectric focusing gel electrophoresis, and gels were stained for peroxidase activity. The isoelectric points of the marker proteins are shown on the right. 
phyte-infected seed (lot 2) grown in the greenhouse (Fig. 4B), and no sporulation was evident. These hyphae did not appear to be convoluted, as has been observed with hyphae of other Neotyphodium species. No hyphae were found in the root tissues of the asymptomatic plants (Fig. 4E). In contrast, plants grown in closed containers from heat-treated, surface-sterilized (lot 2) seed inoculated with Neotyphodium spores displayed the visual symptoms described above, with abundant hyphae and conidia on the outer surfaces of both root and leaf tissues (Fig. 4C and F). Control plants from endophyte-free, noninoculated seed had no fungal hyphae intercellularly or on the epidermis of leaf sheaths (Fig 4A) or roots (Fig 4D).

Pathogenicity of the Neotyphodium isolate from wheat on other plant hosts. The Neotyphodium isolate from wheat caused symptoms on other grasses and cereals after spore inoculation of seed and growth under suboptimal conditions in closed containers. Germination of D. glomerata, Hordeum vulgare, T. aestivum, and Zea mays was reduced by more than $50 \%$ (Table 5). Germination of $F$. arundinacea, with or without its endophyte, $N$. coenophialum, was not reduced. Neotyphodium mycelia was present on the leaf surfaces and roots of $D$. glomerata and T. aestivum at 8 days postinoculation. Neotyphodium mycelia and conidia were found on the leaf surfaces of all inoculated hosts by 16 days postinoculation when assessed microscopically. Disease symptoms of chlorosis and twisting only appeared on $F$. arundinacea and $Z$. mays leaf sheaths and leaves at 16 days postinoculation, when Neotyphodium mycelia also were visible on the vermiculite surface. The leaves from all inoculated plants were shorter in length. $F$. arundinacea infected with $N$. coenophialum showed the least extent of infection of leaf sheaths. Roots of Festuca, Zea, or Hordeum were not infected by 16 days postinoculation, although progressive colonization was detected in Dactylis.

Plant peroxidases and Neotyphodium colonization. The goal of the space mission was to examine whether there are changes in peroxidase activity in wheat after growth in microgravity. Thus, extracts were prepared from both the spaceflight- and earth-grown plants with seedlings that were visually free of disease symptoms. Different isozymes of peroxidase were detected in extracts of roots (pI 5.7) and leaf sheaths (pI 5.2) from the microgravitygrown wheat seedlings compared to extracts from the control seedlings grown simultaneously on earth (Fig. 5). However, the unique isozymes in extracts from the microgravity-grown plants also were found in symptomatic plants derived from the microbial-free lot 5 seed inoculated with the Neotyphodium isolate from wheat and grown in closed containers (Fig. 6). These induced isoforms of peroxidase were not detected in extracts from seedlings from asymptomatic noninoculated lot 5 seed.

\section{DISCUSSION}

Microbiological surveys of spaceflight missions have found microbes that have the potential to colonize plants $(4,26,30,31)$. Some of these organisms are likely to be potential plant pathogens, and their pathogenicity may be enhanced by spaceflight conditions. The wheat cv. Super Dwarf seed allocated to the spaceflight mission flown on the U.S. space shuttle Discovery during February 1995 contained a fungal endophyte with the ability to produce symptoms on spaceflight and ground-control plants during growth under closed suboptimal conditions. The symptoms were caused by a seedborne Neotyphodium species, and thus, the fungus was propagated via maternal transmission. The wheat endophytic fungus was identified as a Neotyphodium species based on its production of smooth hyaline conidia from characteristic phialides $(23,24,34,36)$. The conidial size, 10 to $20 \mu \mathrm{m}$ long and 1.0 to $2.0 \mu \mathrm{m}$ wide, falls within the size range reported for other species of Neotyphodium. For example, $N$. chilense conidia are between 10 and $30 \mu \mathrm{m}$ long and 1 and $1.5 \mu \mathrm{m}$ wide, whereas those from a Neotyphodium species associated with Stipa robusta are between 5.9 and $9.7 \mu \mathrm{m}$ long and 2.0 and $3.4 \mu \mathrm{m}$ wide $(15,23,24,34,36)$.

Two protein bands from the wheat fungal isolate separated by SDS-PAGE cross-reacted with antibodies generated to N. coeno-

TABLE 5. Symptoms caused by inoculation of grass and cereal seed with the Neotyphodium isolate from wheat at 8 and 16 days

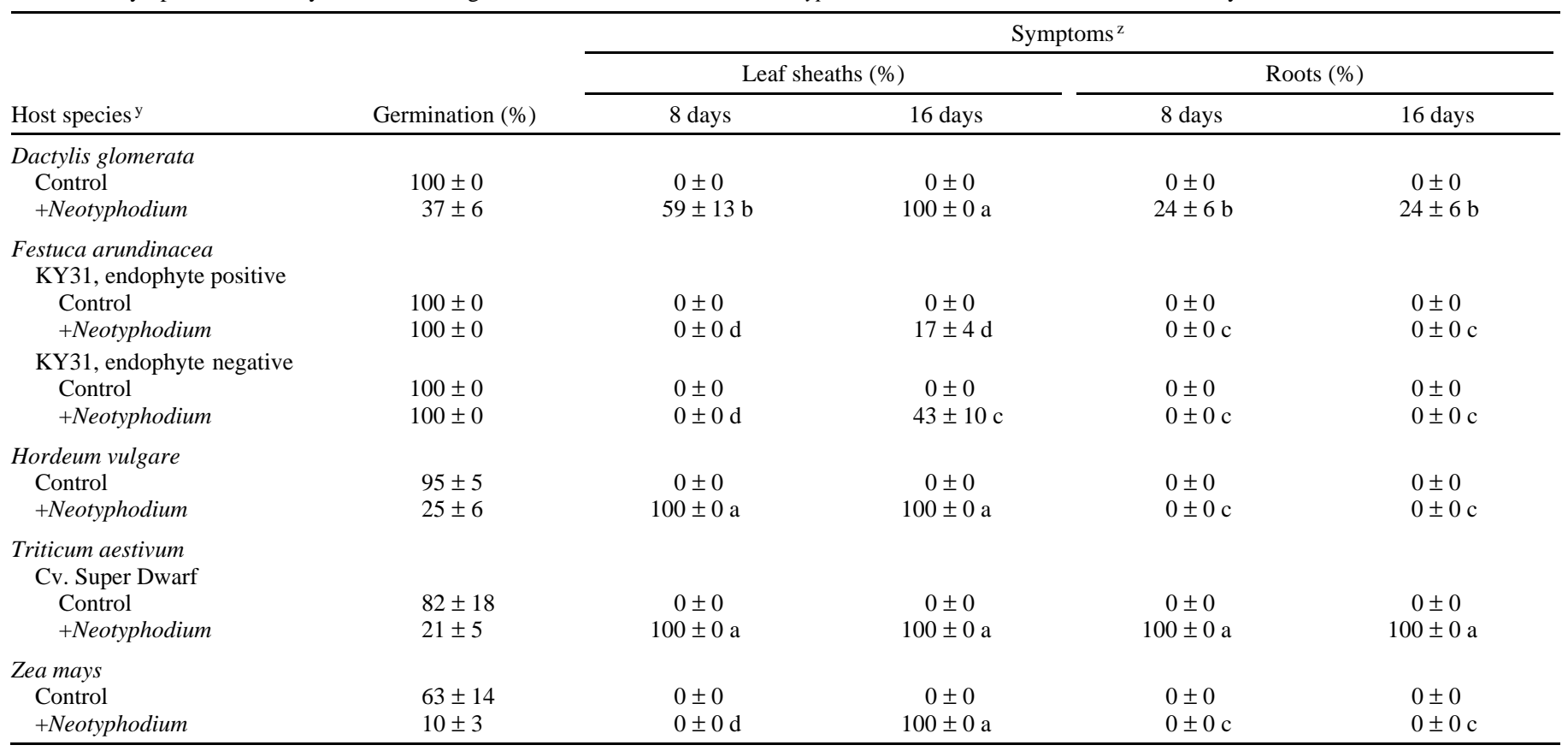

${ }^{y}$ Seeds of the plants listed were inoculated with a suspension of Neotyphodium spores, as described in text. Noninoculated control plants received only surfacesterilization treatments. The plants were grown in closed Magenta boxes (Magenta Corporation, Chicago) and examined for symptoms at 8 and 16 days postplanting.

z Percentage of plants with symptoms on leaf sheaths and roots was estimated for each plant host. Data were transformed by arcsine square-root transformation and are represented as back-transformed means with standard error of five replications each with 20 plants. Comparisons between host species were made for the Neotyphodium-inoculated plants. Differences were found between host species in percent infection of roots and leaves at both 8 and 16 days after inoculation with the Neotyphodium wheat isolate $(\alpha \leq 0.05)$. Means in the same column followed by the same letter are not significantly different. 
phialum, an endophyte of fescue. Thus, our results agree with the findings of C. West, University of Arkansas, Fayetteville (personal communication), that these polyclonal antibodies raised against $N$. coenophialum recognize other Neotyphodium species. Kaiser et al. (15) also reported on an antibody preparation that recognizes different Neotyphodium isolates. However, the aggressive growth habit of the wheat isolate on carbohydrates, especially xylose (24), and its profuse sporulation and ability to cause disease on wheat under stressed conditions differ from that of $N$. coenophialum and other related Neotyphodium species classified in section Albo-lanosa. Generally, these fungal endophytes grow slowly in culture, have limited spore production, and are asymptomatic on their hosts. Some species of $N$. typhinum have been classified as type I, II, or III according to their pathogenic potential (36). Type III isolates cause symptoms of "choke," which are characterized by the formation of fungal reproductive structures or stromata, which replace the inflorescences (36).

Neotyphodium species in section Albo-lanosa are found predominately in the sheath and are not found in roots $(23,24,36)$. However, Kaiser et al. (15) reported that mycelia were detected when roots of Stipa robusta infected with an uncharacterized Neotyphodium species were plated on PDA medium. They also observed mycelia erupting from the leaf tips of endophyte-positive $S$. robusta, a phenomenon that we also have observed in symptomatic wheat. Another Neotyphodium species, N. chilense, is more aggressive in its interaction with its host and grows either intercellularly or intracellularly in orchard grass (24). Morgan-Jones et al. (24) suggested that this Neotyphodium endophyte may become pathogenic under conditions that promote plant stress or during tissue senescence. The Neotyphodium isolate from wheat resembles $N$. chilense in its spore and phialide morphology, as well as in its ability to produce purple pigmentation when grown on a medium of wheat meal or isolated wheat cell walls (A. J. Anderson, unpublished data). It is unknown whether Neotyphodium-infected wheat produces alkaloids or other metabolites that may produce toxins to deter insects. Preliminary results showed that, in contrast to reports for $N$. coenophialum (35), metabolites produced by the fungus after growth on PDA did not inhibit the growth of other fungal plant pathogens (A. J. Anderson and B. Issa, unpublished data).

The Neotyphodium isolate from wheat was asymptomatic in wheat grown under normal greenhouse cultivation, e.g., no visible mycelial growth on plant tissues was apparent and flowering and seed set were unaffected. Asymptomatic growth of Neotyphodium in Super Dwarf wheat occurred intercellularly in leaf sheaths, with no visible signs of infection in or on the root tissues. This interaction between wheat and Neotyphodium resembled the asymptomatic growth of other Neotyphodium isolates in grasses $(6,28$, $29,36)$. In contrast, wheat grown under closed conditions, similar to those in spaceflight from Neotyphodium-infected seed, displayed profuse external growth of mycelia and extensive sporulation. Other symptoms of Neotyphodium infection included mycelial girdling of the leaf sheath accompanied by chlorosis and narrowed or twisted leaf tissues. Plant growth under spaceflight conditions apparently provided a conducive environment for this Neotyphodium species to proliferate and cause disease. Identical disease symptoms also were observed on other plant hosts grown in closed containers after inoculation of seed with the Neotyphodium wheat isolate. Thus, the fungus is not restricted in its host range under these growth conditions. Whereas various species of Neotyphodium commonly are reported as endophytes in asymptomatic grasses (6), such as Festuca $(8,23)$, Dactylis (24), and Stipa (15), to our knowledge the effects of Neotyphodium applied artificially as a spore suspension in a grass-endophyte interaction never have been assessed. It has been proposed that the Neotyphodium endophytes arose from Epichloe species, which may be pathogenic and result in disease or "choke" of seed-bearing heads $(21,29)$, and other Neotyphodium isolates have been documented as pathogens on other nongrass hosts. For example, Acremonium species have been documented as the causal agents of muskmelon collapse (9). In this particular case, the fungus resulted in symptoms predominately in the roots, with little effect on leaves until late in disease development.

For meaningful plant growth and development experiments to be carried out in space, the effects of microbial interactions must be considered. Our findings support the need to screen germ plasm used in spaceflight research to detect surface and endophytic microbial contamination. For example, the introduction of just one Neotyphodium-infected seed can result in infection of and deleterious consequences to other plants in the same closed growth module. In addition, we found that the peroxidase isozyme pattern of wheat cv. Super Dwarf was altered by the presence of the Neotyphodium endophyte (3), making it impossible to fulfill our original goal of identifying the effects of microgravity on plant peroxidase composition. We recommend that plants be examined routinely for microbial sterility at the end of spaceflight missions to ensure that any changes are in response to microgravity and not due to the complications of microbial contamination. Strategies to control pathogens in space are essential to the development of adequate plant growth conditions for future plant experiments on the International Space Station and to maintain the quality and production of food resources in space.

\section{ACKNOWLEDGMENTS}

This research was supported by grants to A. J. Anderson from the NASA Small Payload, NAG 10-01140; 1994-1995; the Rocky Mountain NASA Space Consortium; and the Utah Agricultural Experiment Station. Utah Agricultural Experiment Station Paper 5001. We thank S. Durham for statistical consultation and T. Jones at the USDA Forage and Range Research Laboratories for his discussions on Neotyphodium growth habits and for providing antibodies specific to Neotyphodium.

\section{LITERATURE CITED}

1. Albert, F., and Anderson, A. J. 1987. Effect of Pseudomonas putida colonization on root surface peroxidase activity. Plant Physiol. 85:537-541.

2. Bacon, C. W., and White, J. F., Jr. 1994. Stains, media, and procedures for analyzing endophytes. Pages 47-56 in: Biotechnology of Endophytic Fungi of Grasses. CRC Press, London.

3. Bishop, D. L., MacAdam, J. W., and Anderson, A. J. 1996. Induction of wheat cell-wall associated peroxidases by two fungal pathogens. Page 204 in: Abstr. Extracell. Matrix Plants: Mol. Cell. Dev. Biol. Keystone, Silverthorne, CO.

4. Brockett, R. M., Ferguson, Z. J. K., and Henney, M. R. 1978. Prevalence of fungi during Skylab missions. Appl. Environ. Microbiol. 36:243-246.

5. Bugbee, B. 1989. Controlled environment crop production: Hydroponics versus lunar regolith. Pages 107-129 in: Lunar Agriculture. D. Henninger and D. Ming, eds. American Society of Agronomy, Madison, WI.

6. Clay, K. 1990. Fungal endophytes of grasses. Annu. Rev. Ecol. Syst. 21: 275-297.

7. Cowles, J. R., Scheld, H. W., Lemay, R., and Peterson, C. 1984. Growth and lignification in seedlings exposed to eight days of microgravity. Ann. Bot. 54(Suppl. 3):33-48.

8. Gams, W., Petrini, O., and Schmidt, D. 1990. Acremonium uncinatum, a new endophyte in Festuca pratensis. Mycotaxon 37:67-71.

9. García-Jiménez, J., Velázquez, M. T., Jordá, C., and Alfaro-García, A. 1994. Acremonium species as the causal agent of muskmelon collapse in Spain. Plant Dis. 78:416-419.

10. Gasset, G., Tixador, R., Eche, B., Lapchine, L., Moatti, N., Toorop, P., and Woodringh, C. 1994. Growth and division of Escherichia coli under microgravity conditions. Res. Microbiol. 145:111-120.

11. Gwinn, K. D., Collins-Shephard, M. H., and Reddick, B. B. 1991. Tissue print-immunoblot, an accurate method for the detection of Acremonium coenophialum in tall fescue. Phytopathology 81:747-748.

12. Halstead, T. W., and Dutcher, F. R. 1987. Plants in space. Annu. Rev. Plant Physiol. 38:317-345.

13. Hoefer Scientific Instruments. 1994. Protein Electrophoresis Applications Guide. Hoefer Scientific Instruments, San Francisco.

14. Kaeena, M. A., and Todd, P. 1995. Low gravity and inertial effects on the growth of E. coli and B. subtilis in semi-solid media. Am. Soc. Gravitational Biol. Bull. 7 (1):10-15. 
15. Kaiser, W. J., Bruehl, G. W., Davitt, C. M., and Klein, R. E. 1996. Acremonium isolates from Stipa robusta. Mycologia 88:539-547.

16. Krikorian, A. D., and Levine, H. G. 1992. Effects of spaceflight on growth and cell division in higher plants. Adv. Space Biol. Med. 2:181-209.

17. Kropp, B. R., Thomas, E., Pounder, J. I., and Anderson, A. J. 1996. Increased emergence of spring wheat by Pseudomonas chlororaphis isolate 2E3 under field and laboratory conditions. Biol. Fertil. Soils 23:200-206.

18. Levine, H. G., and Krikorian, A. D. 1992. Chromosomes and plant cell division in space: Environmental conditions and experimental details. Adv. Space Res. 12:73-82.

19. Levine, H. G., and Krikorian, A. D. 1992. Shoot growth in aseptically cultivated daylily and Haplopappus plantlets after a 5-day spaceflight. Physiol. Plant 86:349-359.

20. Levine, H. G., and Krikorian, A. D. 1996. Enhanced root production in Haplopappus gracilis grown under spaceflight conditions. J. Gravitational Physiol. 2(2):17-28.

21. Leuchtmann, A., and Clay, K. 1990. Isozyme variation in the Acremonium/Epichloë fungal endophyte complex. Phytopathology 80:1133-1139.

22. MacAdam, J. W., Sharp, R. E., and Nelson, C. J. 1992. Peroxidase activity in the leaf elongation zone of tall fescue. II. Spatial distribution of apoplastic peroxidase activity in genotypes differing in length of the elongation zone. Plant Physiol. 99:879-885.

23. Morgan-Jones, G., and Gams, W. 1982. Notes on Hyphomycetes. XLI. An endophyte of Festuca arundinacea and the anamorph of Epichloe typhina, new taxa in one of two new sections of Acremonium. Mycotaxon 15:311-318.

24. Morgan-Jones, G., White, J. F., Jr., and Piontelli, E. L. 1990. Endophytehost associations in forage grasses. XIII. Acremonium chilense, an undescribed endophyte occurring in Dactylis glomerata in Chile. Mycotaxon 39:441-454.

25. Murashige, T., and Skoog, F. 1962. A revised medium for rapid growth and bio assays with tobacco tissue cultures. Physiol. Plant 15:473-497.

26. Nelson, B. 1987. The role of plant pathology in development of controlled ecological life support systems. Plant Dis. 71:580-584.

27. Schenk, R. U., and Hildebrandt, A. C. 1972. Medium and techniques for induction and growth of monocotyledonous and dicotyledonous plant cell cultures. Can. J. Bot. 50:199-204.

28. Sieber, T., Riesen, T. K., Muller, E., and Fried, P. M. 1988. Endophytic fungi in four winter wheat cultivars (Triticum aestivum L.) differing in resistance against Stagonospora nodorum (Berk.) Cast. \& Germ. =Septoria nodorum (Berk.) Berk. J. Phytopathol. 122:289-306.

29. Siegel, M. R. 1993. Acremonium endophytes: Our current state of knowledge and future directions for research. Agric. Ecosyst. \& Environ. 44: 301-321.

30. Taylor, G. R. 1974. Space microbiology. Annu. Rev. Microbiol. 28:121-137.

31. Taylor, G. R., Henney, M. R., and Ellis, W. L. 1973. Changes in the fungal autoflora of Apollo astronauts. Appl. Microbiol. 26:804-813.

32. Tripathy, B. C., Brown, C. S., Levine, H. G., and Krikorian, A. D. 1996. Growth and photosynthetic responses of wheat plants grown in space. Plant Physiol. 110:801-806.

33. Tixador, R., Gasset, G., Eche, B., Moatti, N., Lapchine, L., Woldringh, C., Toorop, P., Moatti, J. P., Delmotte, F., and Tap, G. 1994. Behavior of bacteria and antibiotics under space conditions. Aviat. Space Environ. Med. 551-555.

34. Von Arx, J.A. 1981. The genera of fungi sporulating in pure culture. 3rd ed. J.Cramer, Vaduz, Germany.

35. White, J. F., Jr., Morgan-Jones, G., and Morrow, A. C. 1993. Taxonomy, life cycle, reproduction and detection of Acremonium endophytes. Agric. Ecosyst. \& Environ. 44:13-37.

36. White, J. F., Jr., and Cole, G. T. 1985. Endophyte-host associations in forage grasses. III. In vitro inhibition of fungi by Acremonium coenophialum. Mycologia 77:487-489. 